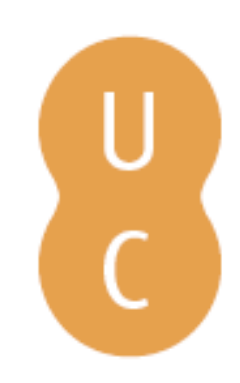

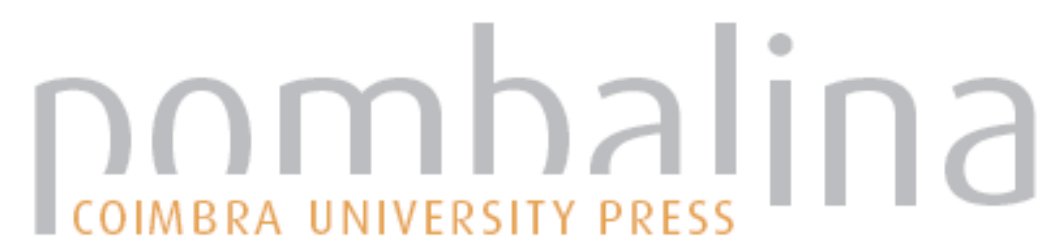

\title{
Large-scale mutation screening in sudden cardiac death (SCD)
}

\begin{tabular}{ll} 
Autor(es): & $\begin{array}{l}\text { Allegue, C.; Brión, M.; Rodríguez-Calvo, M. S.; Gil, R.; Torres, M.; } \\
\text { Concheiro, L.; Carracedo, A. }\end{array}$ \\
Publicado por: & $\begin{array}{l}\text { Imprensa da Universidade de Coimbra; International Academy of Legal } \\
\text { Medicine }\end{array}$ \\
$\begin{array}{ll}\text { URL } \\
\text { persistente: }\end{array}$ & URI:http://hdl.handle.net/10316.2/31809 \\
DOI: & DOI:http://dx.doi.org/10.14195/978-989-26-0173-1_38 \\
Accessed : & 26-Apr-2023 15:16:20 \\
\hline
\end{tabular}

A navegação consulta e descarregamento dos títulos inseridos nas Bibliotecas Digitais UC Digitalis, UC Pombalina e UC Impactum, pressupõem a aceitação plena e sem reservas dos Termos e Condições de Uso destas Bibliotecas Digitais, disponíveis em https://digitalis.uc.pt/pt-pt/termos.

Conforme exposto nos referidos Termos e Condições de Uso, o descarregamento de títulos de acesso restrito requer uma licença válida de autorização devendo o utilizador aceder ao(s) documento(s) a partir de um endereço de IP da instituição detentora da supramencionada licença.

Ao utilizador é apenas permitido o descarregamento para uso pessoal, pelo que o emprego do(s) título(s) descarregado(s) para outro fim, designadamente comercial, carece de autorização do respetivo autor ou editor da obra.

Na medida em que todas as obras da UC Digitalis se encontram protegidas pelo Código do Direito de Autor e Direitos Conexos e demais legislação aplicável, toda a cópia, parcial ou total, deste documento, nos casos em que é legalmente admitida, deverá conter ou fazer-se acompanhar por este aviso.

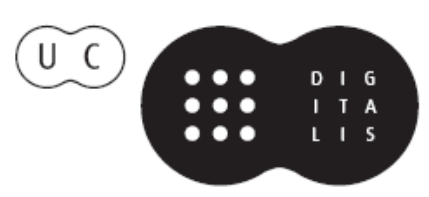




\section{Duarte Nuno Vieira Anthony Busuttil \\ Denis Cusack • Philip Beth}
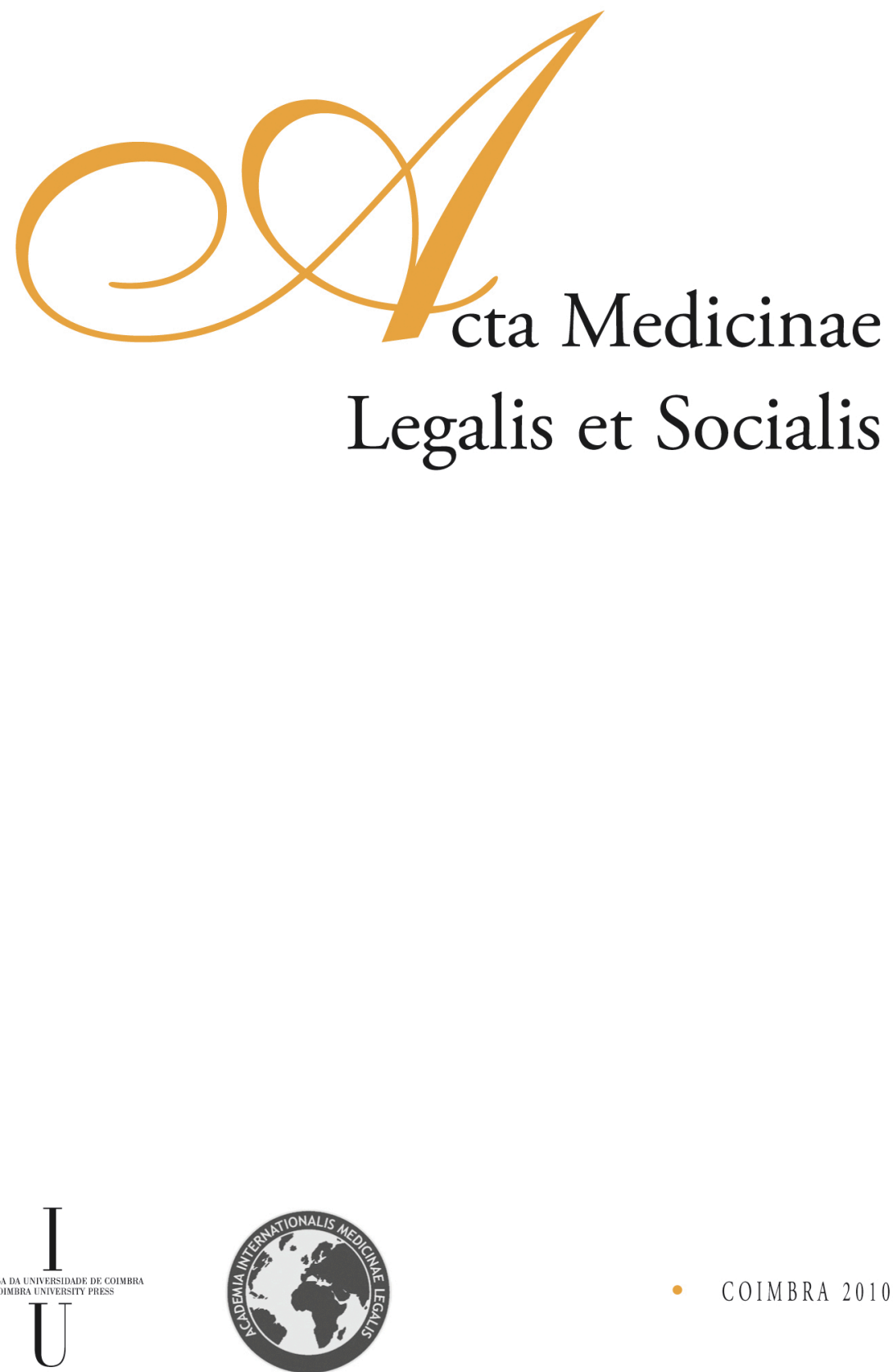
C. Allegue ${ }^{1}$, M. Brión ${ }^{1,2}$, M. S. Rodríguez-Calvo ${ }^{3}$, R. Gil ${ }^{4}$, M. Torres ${ }^{4}$,

L. Concheiro ${ }^{3}$, A. Carracedo ${ }^{1,4}$

${ }^{1}$ Genomic Medicine Group, University of Santiago de Compostela, CIBERER, Spain

${ }^{2}$ Hospital-University Complex of Santiago, Santiago de Compostela, Spain

${ }^{3}$ Department of Pathology and Forensic Sciences, University of Santiago de Compostela, Spain

${ }^{4}$ Nacional Genotyping Center, University of Santiago de Compostela, Spain

\title{
LARGE-SCALE MUTATION SCREENING IN SUDDEN CARDIAC DEATH (SCD)
}

\begin{abstract}
One of the most common causes of death in developed countries is sudden cardiac death (SCD). Structural and arrhythmogenic diseases are the main abnormalities found in SCD cases, especially in the young, and both are due to genetic heart disorders such as hypertrophic cardiomyopathy, Long QT syndrome or Brugada Syndrome. In recent years, significant advances have been made in understanding the genetic basis of SCD. We have developed a high-throughput strategy using a semi-automated MALDI-TOF mass spectrometry system for detecting the most frequent mutations in different syndromes that can result in SCD.
\end{abstract}

\section{Introduction}

Most of the forensic pathologist workload deals with natural deaths and more than $50 \%$ of cases are sudden cardiac deaths (SCD). In about 1 of every 20 cases of SCD, the classical autopsy cannot establish the cause of death, even after the heart has been examined by an expert cardiac pathologist. This is then called Sudden Arrhythmic Death Syndrome, and most have a genetic component. The conditions responsible for SCD can be classified in two groups: a) structural anomalies, being the most frequent hypertrophic cardiomyopathy (HCM) and arrhythmogenic right ventricular cardiomyopathy (ARVC), and b) non structural anomalies or channelopaties, such as long QT syndrome (LQTS) and Brugada syndrome $(1,2)$.

In people over 35 , the cause of death is usually due to coronary heart disease. When it comes to younger people and children, cardiomyopathies, congenital heart disease and conduction disorders take the lead (3).

Up to now many genes have been associated with the different syndromes responsible for SCD, making difficult the genetic diagnosis by classical technologies such as sequencing. Based on this knowledge, we have developed a high-throughput strategy using a semi-automated MALDI-TOF mass spectrometry for detecting the most frequent mutations in different syndromes. More than 600 mutations of HCM (4) genes and almost 400 mutations of LQTS genes have been analysed in sudden cardiac death cases and relatives. HCM is defined as a clinically heterogeneous but relatively common autosomal dominant genetic disease with a prevalence of 1:500 
in a general population of healthy young adults (5). Congenital LQTS comprises a distinct group of cardiac channelopathies characterized by delayed repolarization of the myocardium, QT interval prolongation, an specific form of polymorphic ventricular tachycardia called Torsade des Pointes can also be found and the risk for syncope, seizures, and sudden cardiac death is higher in the setting of a structurally normal heart (6). It is a genetically heterogeneous disease affecting 1 in 5000 persons, with a natural history ranging from sudden death in infancy to asymptomatic longevity (7).

Efficiency and accuracy of the system have been evaluated and preliminary results are presented.

\section{Materials and methods}

Samples:

DNA was extracted from embedded paraffin tissues or from peripheral blood after autopsy in sudden cardiac death cases in individuals of 1-40 years old.

Sample inclusion criteria was:

A) Samples obtained after autopsy:

- Negative autopsies

- HCM evidences found after autopsy.

- Autopsy cases with family medical history of cardiac events such as sudden cardiac death in relatives.

B) Patients after sudden cardiac event recuperation

- The study includes two large families with family medical history of sudden cardiac death.

\section{Mutation databases:}

Familiar Hypertrophic Cardiomyopathy Mutation Database http://www.angis.org. au/Databases/Heart/heartbreak.html

Cardiogenomics Mutation Database http://cardiogenomics.med.harvard.edu/home

The Human Gene Mutation Database (Institute of Medical Genetics, Cardiff) http://www.hgmd.org/

\section{Mutation detection method:}

We have developed a rapid and efficient mutation detection system based on semiautomated MALDI-TOF mass spectrometry using the Sequenom MassArray system. This typing assay uses iPLEX GOLD assay reactions that ends after a Single Base Extension (SBE). Extension primer hybridise one base before the mutagenic locus. Sample genotyping is performed because of the addition of one ddNTP to the extension primer which is complementary to the locus we are studying. The extension primer is now one base longer. The mass difference after the iPLEX reaction is detected by means of matrix assisted laser desorption ionization time-of-flight mass spectrometry. Samples are automatically genotyped from each mass spectrum produced. Multiple sites can be typed simultaneously by multiplexing PCR and the extension reaction (8). 
Two different strategies were designed to analyze on one hand $688 \mathrm{HCM}$ genetic variants in 102 samples and 432 LQTS genetic variants in 75 samples.

HCM Strategy: HCM strategy include the detection of mutations described in literature not only in sarcomeric genes but also in other genes previously described as implicated in HCM. Number of genetic variants in each gene is shown in table 1.

Genetic variants added in our HCM mutation detection chip, including causal mutations and some polymorphic variants are distributed into 44 plexes as shown in table 2.

LQTS Strategy: Our LQTS screening strategy include mutations in the three most prevalent genes implicated in the disease: KCNQ1 (implicated in LQT1 syndrome), KCNH2 (implicated in LQT2 syndrome) and SCN5A (implicated not only in LQT3 syndrome but also in Brugada syndrome). Genetic variants analyzed in each gene also include causal mutations and some polymorphisms. Distribution of the mutation into 38 plexes is shown in tables 3, 4 and 5 .

\section{Results}

CM Strategy results: Genotyping success rate was $84 \%$ in DNA extracted from peripheral blood and $74 \%$ in DNA extracted from paraffin embedded tissues. A total of 19 mutated samples were found out of 102 total analysed samples. Most of the variants were found in myosin binding protein $\mathrm{C}$ (MYBPC3) where a total of 9 cases with 4 different genetic variants were found. A total of 9 more cases were mutated in Troponin T (TNNT2), 1 more case was found mutated for myosin heavy chain gene (MYH7) and 1 sample was found as positive mutation carrier Troponin I gene (TNNI3).

Results can be found in table 6 . All the genetic variants detected in the platform were confirmed by direct sequencing. Variation R326Q detected in MYBPC3 gene as an example of a mutation found in Sequenom MassArrayä system is shown in figure 1 and the confirmation of this mutation by direct sequencing can be seen in figure 2 .

LQTS Strategy results: Genotyping success rate was $84 \%$ in DNA extracted from peripheral blood. In this case, a total of 75 samples were analysed, 46 of them analysed for KCNQ1, KCNH2 and SCN5A and 29 samples specifically genotyped for SCN5A study.

2 samples up to 46 were found as positive mutation carriers with 2 different genetic variants in KCNQ1 gene and 1 case up to 29 was a mutation carrier in SCN5A gene. The results can be seen in table 7 . All the genetic variants detected in the platform were confirmed by direct sequencing.

\section{Discussion}

Sequenom MassArray system efficiency for our mutation screening strategy is demonstrated since the genotyping success rate value is up to $80 \%$ in both strategies: $\mathrm{MCH}$ and LQTS. This value is lower when we analyze DNA extracted from paraffin embedded after formol fixation in which the quality of the DNA is worst. In spite of 
the low DNA quality in these cases we were able to get good results in this degraded samples as the length of the analysed sequences in Sequenom MassArray system is short.

The accuracy is also proved as all the mutation detected was confirmed by means of direct sequencing in all cases.

This fast mutation screening may help to clarify the cause of the death after a non conclusive autopsy. Relatives of a deceased person can benefit from the screening by identifying mutation carriers in the family so our mutation detection screening has a useful application not only in the forensic sphere but also in clinical field.

\section{Conclusions}

Sequenom MassArray system allows us to get really fast analysis results since the genotyping analysis can be developed in 48 hours. The flexibility of the platform make possible to add new mutations as they are being described in the literature.

Low quality DNA samples can be easily genotyped even if they have been preserved for a long time or if they have been paraffin embedded after formol fixation

In addition, Sequenom MassArray genotyping is more cost effective than performing the analysis by means of traditional sequencing and the reliability of the platform is absolute since all genetic variants found were confirmed by direct sequencing.

\section{References}

1. M.S RODRÍGUEZ-CALVO, M. BRION, C. ALLEGUE, L. CONCHEIRO, A. CARRACEDO. Molecular Genetics of Sudden Cardiac Death. For Sci Int 182:1-12, 2008.

2. J. INGLES, C. SEMSARIAN. Sudden cardiac death in the young. Int Med J 37:32-7, 2007.

3. T.J. BOWKER, D.A. WOOD, M.J. DAVIES, M.N. SHEPPARD, N.R.B. CARY, J.D.K. BURTON, D.R. CHAMBERS, S. DAWLING, H.L. HOBSON, S.D.M. PYKE, R.A. RIEMERSMA AND S.G. THOMPSON. Sudden, unexpected cardiac or unexplained death in England: a national survey. QJ Med 96:269-79, 2003.

4. M. BRION, C. ALLEGUE, L. MONSERRAT, M. HERMIDA, A. CASTRO-BEIRAS, A. CARRACEDO. Large-scale analysis of HCM mutations in sudden cardiac death. For Sci Int: Genetics Suppl. Series 1:549-550, 2008.

5. B.J. MARON, J.M. GARDIN, J.M. FLACK, S.S. GIDDING, T.T. KUROSAKI, D.E. BILD. Prevalence of hypertrophic cardiomyopathy in a general population of young adults. Echocardiographic analysis of 4111 subjects in the CARDIA study, Circulation 92:785-789, 1995.

6. M.T. KEATING, M.C. SANGUINETTI. Molecular and cellular mechanisms of cardiac arrhythmias, Cell 104:569-580, 2001.

7. M.J. ACKERMAN, D.E. CLAPHAM Ion channels-basic science and clinical disease, N Engl J Med 336:1575-1586, 1997.

8. http://www.sequenom.com/ 


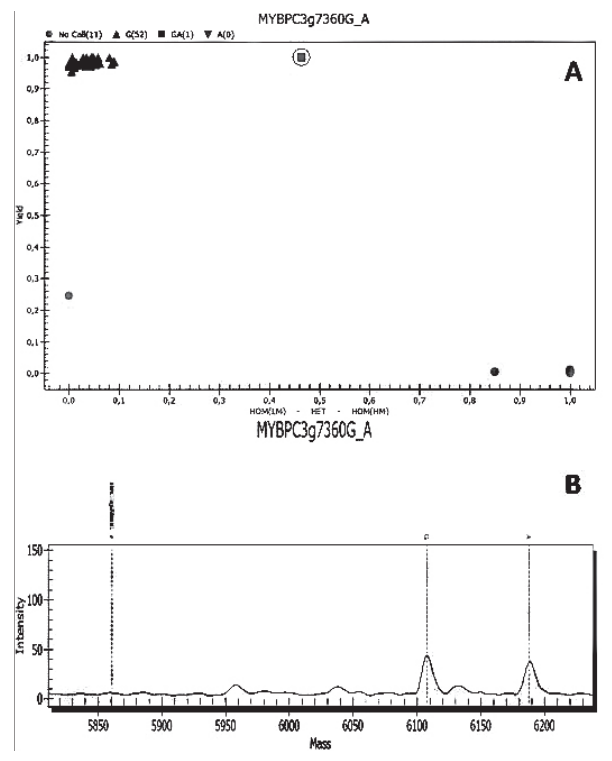

Figure - 1

R326Q mutation detected in MYBPC3 gene by means of Sequenom MassArray System: A) Cluster plot aspect B)spectrum aspect of the heterozygous sample

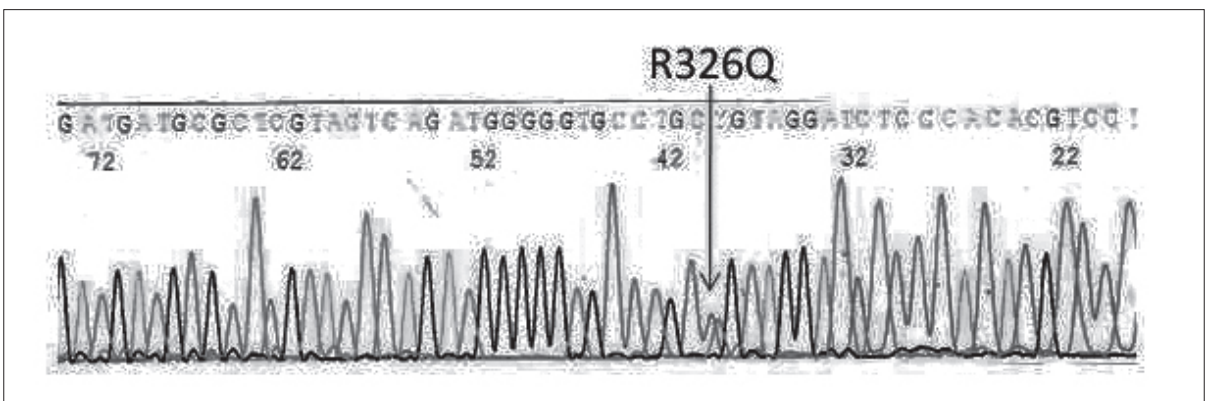

Figure 2 - Confirmation of R326Q detected in MYBPC3gene by direct sequencing.

\begin{tabular}{lccc}
\hline \multicolumn{1}{c}{ Sarcomeric genes } & Genetic variants & Other genes & Genetic variants \\
\hline MYH7 & 280 & PRKAG2 & 4 \\
\hline MYBPC3 & 249 & TCAP & 3 \\
\hline MYL2 & 14 & GLA & 1 \\
\hline MYL3 & 11 & MYO6 & 1 \\
\hline TNNT2 & 45 & MYLK2 & \\
\hline TNNI3 & 35 & & \\
\hline TNNC1 & 4 & & \\
\hline TPM1 & 14 & & \\
\hline ACTC & 9 & & \\
\hline TTN & 10 & & \\
\hline MYH6 & 6 & & \\
\hline
\end{tabular}

Table 1 - Number of genetic variants analyzed in each gene in HCM strategy. 


\begin{tabular}{|c|c|}
\hline Number of plexes & Number of genetic variants \\
\hline 1 PLEX & 23 \\
\hline 2 PLEXES & 22 \\
\hline 3 PLEXES & 21 \\
\hline 4 PLEXES & 20 \\
\hline 3 PLEXES & 19 \\
\hline 4 PLEXES & 18 \\
\hline 4 PLEXES & 17 \\
\hline 7 PLEXES & 16 \\
\hline 4 PLEXES & 15 \\
\hline 4 PLEX & 13 \\
\hline 1 PLEXES & 12 \\
\hline 2 PLEX & 11 \\
\hline 1 PLEXES & 8 \\
\hline 1 PLEX & 7 \\
\hline 1 PLEX & 5 \\
\hline 1 PLEX & 4 \\
\hline 1 PLEX & 3 \\
\hline
\end{tabular}

Table 2 - Distribution of the genetic variants into plexes in HCM strategy.

\begin{tabular}{|c|c|}
\hline Number of plexes & Number of genetic variants \\
\hline 1 PLEXES & 19 \\
\hline 1 PLEX & 17 \\
\hline 1 PLEX & 10 \\
\hline 2 PLEX & 8 \\
\hline 2 PLEX & 7 \\
\hline 5 PLEX & 6 \\
\hline 1 PLEX & 4 \\
\hline
\end{tabular}

Table 3 - Distribution of the genetic variants into plexes in KCNQ1 strategy

\begin{tabular}{|c|c|}
\hline Number of plexes & Number of genetic variants \\
\hline 1 PLEXES & 23 \\
\hline 1 PLEX & 22 \\
\hline 1 PLEX & 19 \\
\hline 1 PLEX & 16 \\
\hline 4 PLEX & 5 \\
\hline 7 PLEX & 4 \\
\hline
\end{tabular}

Table 4 - Distribution of the genetic variants into plexes in KCNH2 strategy 


\begin{tabular}{|c|c|}
\hline Number of plexes & Number of genetic variants \\
\hline 1 PLEXES & 19 \\
\hline 2 PLEX & 18 \\
\hline 2 PLEX & 17 \\
\hline 1 PLEX & 15 \\
\hline 1 PLEX & 11 \\
\hline 1 PLEX & 7 \\
\hline 1 PLEX & 6 \\
\hline
\end{tabular}

Table 5 - Distribution of the genetic variants into plexes in SCN5A strategy

\begin{tabular}{|c|c|c|c|}
\hline Gene & Genetic variant & rs (dbSNP) & Number of cases \\
\hline MYBPC3 & R326Q & rs34580776 & 2 \\
\hline MYBPC3 & K814del & & 1 \\
\hline MYBPC3 & A216T & & 1 \\
\hline MYBPC3 & Q689H & & 5 \\
\hline TNNT2 & K247R & & 9 \\
\hline MYH7 & M982T & & 1 \\
\hline
\end{tabular}

Table 6. Results found in HCM strategy

\begin{tabular}{ccc}
\hline Gene & Genetic variant & Number of cases \\
\hline KCNQ1 & G325R & 1 \\
\hline KCNQ1 & R366W & 1 \\
\hline SCN5A & K1512W & 1 \\
\hline
\end{tabular}

Table 7 - Results found in LQTS strategy 